\title{
Erratum to: Inside Asylum Bureaucracy: Organizing Refugee Status Determination in Austria
}

\section{Erratum to:}

J. Dahlvik, Inside Asylum Bureaucracy: Organizing Refugee Status Determination in Austria, IMISCOE Research Series, https://doi.org/10.1007/978-3-319-63306-0

The book was inadvertently published without the inclusion of funder statement and logo on the copyright page. The copyright page has been updated in the book. 